\title{
PENGETAHUAN DAN SIKAP REMAJA TERHADAP PENGGUNAAN NAPZA DI SEKOLAH MENENGAH ATAS DI KOTA SEMARANG
}

\author{
Angga mahargia yunanta firdaus ${ }^{1}$, Eni hidayati $^{2}$ \\ ${ }^{1}$ Program Studi Ilmu Keperawatan, FIKKes Universitas Muhammadiyah Semarang \\ Anggayunanta21@gmail.com
}

\begin{abstract}
ABSTRAK
NAPZA merupakan singkatan dari Narkoba, Psikotropika, dan Zat Adiktif lainnya. Penggunaan NAPZA sangat membahayakan bagi kesehatan baik mental maupun fisik penggunanya. Pengguna NAPZA beresiko gangguan perkembangan otak, bunuh diri dan depresi kehilangan memori, risiko tinggi terhadap perilaku seksual, kecanduan, pengambilan keputusan terganggu, prestasi akademis yang buruk, kekerasan, dan kecelakaan kendaraan bermotor. Penggunaan NAPZA juga merusak masa depan penggunanya dan juga masa depan Bangsa. Penelitian ini bertujuan untuk menganalisis hubungan tingkat pengetahuan dan sikap terhadap penggunaan NAPZA pada remaja di sekolah mengah atas di kota Semarang. Jenis Penelitian ini merupakan penelitian kuantitatif dengan metode survei analitik. menggunakan rancangan survei cross sectional. Sampel penelitan sebanyak 150 remaja yang memenuhi kriteria menggunakan kuesioner kemudian diuji menggunakan uji chi square pada tingkat kepercayaan 95\% dari program SPSS versi 19. Hasil penelitian menunjukkan bahwa ada hubungan positif dan Signifikan antara pengetahuan dan sikap terhadap penggunaan NAPZA remaja di sekolah mengah atas di kota Semarang. Nilai $p=0.000$ dan nilai $r=0.343$ pada uji pengetahuan dan penggunaan NAPZA membuktikan bahwa pengetahuan merupakan faktor pendukung penggunaan NAPZA. Nilai $p=0.003$ dan nilai $r=0.236$ mengindikasikan bahwa ada korelasi antara sikap dengan penggunan NAPZA, dan pengetahuan dan sikap menghasilkan nilai Chi Square signifikasi $=0,202$. Berdasarkan ketentuan analisis Chi Square dimana nilai probabilitas (p) kurang dari 0,05 artinya tidak terdapat hubungan yang signifikan antara tingkat pengetahuan dengan sikap pada remaja. Pengetahuan tentang NAPZA dan penyalahgunaannya akan mengarahkan remaja untuk tidak pernah menggunakan bahkan mencoba zat berbahaya tersebut serta bersikap menolak ajakan teman maupun pengaruh lingkungan untuk menggunakannya. Dengan demikian menjadi sangat penting bagi semua pihak baik sekolah maupun orang tua untuk terus memberikan pengarahan yang baik mengenai bahayanya penyalahgunaan NAPZA bagi masa depan remaja.
\end{abstract}

Kata kunci: Remaja, Kecanduan media sosial, Motivasi belajar

\section{ANALYZE THE RELATIONSHIP OF THE LEVEL OF KNOWLEDGE AND ATTITUDE TOWARDS THE USE OF DRUGS IN TEENS IN SCHOOL MENGAH TOP IN SEMARANG CITY}

\begin{abstract}
IT stands for drugs, psychotropic drugs, and other addictive substances. The use of DRUGS is very harmful for the health of both mental as well as physical users. People who use drugs are at risk of impaired brain development, suicide, depression and memory loss, against the high risk sexual behavior, addiction, impaired decision making, poor academic achievement, violence, and motor vehicle accidents. The use of DRUGS also damage future users and also the future of the nation. This research aims to analyze the relationship of the level of knowledge and attitude towards the use of DRUGS in teens in school mengah top in Semarang city. Type of this research is quantitative research with survey method is analytic. using the draft survey of cross sectional. The sample for the study as many as 150 teens who meet the criteria using keudian questionnaires were tested using the chi square test on a confidence level of $95 \%$ of the program SPSS version 19. The results showed that there is a positive and significant relationship between knowledge and attitudes towards the use of DRUGS in mengah school teen top in Semarang city. The value $p=0000$ and the value of $r=0.343$ on a test of knowledge and the use of DRUGS prove that knowledge is a factor supporting the use of DRUGS.The value $p=0.003$ and value $r=0.236$ indicates that there is a correlation between attitudes with use of
\end{abstract}


Jurnal Keperawatan Jiwa, Volume 6 No 1, Hal 1 - 7, Mei 2018

FIKKes Universitas Muhammadiyah Semarang bekerjasama dengan PPNI Jawa Tengah

DRUGS, and the knowledge and attitude to produce the value of the Chi Square $=0.202$ significance. The Chi Square analysis based on where the value of the probability ( $p$ ) of less than 0.05 means there is no significant relationship between the level of knowledge with attitude in teenagers. Knowledge about DRUGS and abuse will direct teenagers to never use even attempting the hazardous substances as well as being friends or refuse the influence of environment to use it. Thus it becomes very important for all parties to either the school or parents to continue to provide a good briefing about the dangers of the misuse ofDRUGS for the future of youth.

Keywords: adolescent, addicted to social media, the motivation of learning

\section{PENDAHULUAN}

NAPZA merupakan singkatan dari Narkoba, Psikotropika, dan Zat Adiktif lainnya. Pada dunia kesehatan, NAPZA memberikan manfaat yang cukup besar bagi kesembuhan dan keselamatan manusia, namun demikian untuk saat ini penggunaan NAPZA seringkali disalah gunakan (Partodiharjo, 2008). Penyalahgunaan NAPZA adalah penggunaan NAPZA yang digunakan bukan untuk tujuan pengobatan dengan jumlah berlebih, teratur dan berlangsung cukup lama, sehingga menyebabkan gangguan kesehatan fisik serta gangguan pada perilaku dan kehidupan sosialnya (Martono dan Joewana, 2008). Menurut Mayer et al (2009) penyalahgunaan NAPZA yaitu masalah kesehatan publik yang penting dimana secara langsung akan berdampak pada ekonomi, kesehatan dan juga sosial. Laporan Tahunan Badan Narkotika Nasional (BNN) memperlihatkan terjadinya peningkatan kasus-kasus penyalahgunaan NAPZA. Tahun 2016 tercatat 40-50 orang per hari dan tahun 2017 naik menjadi 57 orang perhari kasus penyalahgunaan narkoba di Indonesia dan menyebabkan kematian.

Provinsi Jawa Tengah sepanjang tahun 2017 merupakan salah satu Provinsi dengan angka penggunaan Narkoba yang cukup tinggi. Berdasarkan penelitian terbaru yang dilakukan oleh BNNP yang dipaparkan dalam portal berita online kompas (2017) bahwa ada sekitar 1,9\% penduduk Jawa Tengah tercatat mengkonsumsi Narkoba. Hasil survey tahun 2017 di Jawa Tengah menunjukkan bahwa terdapat 500 ribu penduduk terlibat penyalahgunaan obat-obat terlarang tersebut. Lebih lanjut dijelaskan bahwa ada sepuluh Kota atau Kabupaten di Provinsi Jawa Tengah yang termasuk rawan peredaran NAPZA, yaitu Kota Semarang, Solo, Kabupaten Banyumas, Cilacap, Magelang, Sragen, Jepara, Batang, Pemalang dan Wonosobo.
Semarang merupakan kota pelajar, budaya dan pariwisata memiliki tingkat mobilias yang tinggi sehingga mengakibatkan kota tersebut rawan dengan penyalahgunaan Narkoba. Berdasarkan data Bagian Operasi Polrestabes Semarang dalam portal online koran-sindo (2015) tercatat 100 kasus Narkoba. Jumlah tersebut meningkat sampai $26,5 \%$ dari tahun 2014 berjumlah 79 kasus.

Data Tindak Pidana Narkoba tahun 2007-2011 (dalam BNN, 2012) menunjukkan bahwa jumlah tertinggi tersangka kasus Narkoba di Indonesia maupun di provinsi Jawa Tengah berada pada jenjang pendidikan SMA, prosentase pengguna NAPZA pada tingkat SMA di Indonesia yaitu sebesar 61,9\% dengan jumlah total kasus sebanyak 117.147 orang. Penyalahgunaan NAPZA terbukti memberikan efek negatif sebagaimana telah dipaparkan dalam Survei Nasional Perkembangan Penyalahgunaan dan Peredaran Gelap Narkoba Pada Kelompok Pelajar dan Mahasiswa di 16 provinsi di Indonesia pada tahun 2011, diantaranya adalah adanya penurunan aktivitas dan prestasi di sekolah, terganggunya aktivitas sehari-hari, dan kecenderungan dalam bersikap agresif.

Remaja merupakan indidvidu yang sedang mengalami masa perubahan pada semua aspek dalam dirinya, yaitu perubahan dari kondisi anak-anak menuju dewasa (Hidayah, 2009). Remaja adalah mereka yang berada pada usia 12-18 tahun (Hasibuan, 2011). Perkembangan remaja sangat rentan terhadap pengaruh dari lingkungan dalam kehidupan sehari-hari (Olivia, 2010). Masa transisi perkembangan remaja dari anak-anak menuju dewasa tidak hanya mengenai usia namun juga melibatkan perubahan-perubahan biologis, kognitif, dan sosioemosional. Perubahan perilaku anak, ada yang mengarah ke arah positif dan ada yang ke arah negatif. Perilaku negatif salah satu diantaranya adalah remaja dengan perilaku 
kebiasaan konsumsi alkohol (Sofia \& Adiyanti, 2013).

Dampak dari penyalahgunaan NAPZA diantaranya adalah kerusakan fisik, mental, emosional dan juga spiritual (Ali, 2007). Selain itu, NAPZA juga mempunyai dampak negatif yang sangat luas baik secara fisik, psikis, ekonomi, sosial budaya, hankam serta berbagai unsur kehidupan lainnya. Banyaknya dampak yang dialami oleh penyalahguna NAPZA sehingga diperlukanya program pengobatan bagi yang sudah mengalami penyalahgunan NAPZA serta antisipasi bagi yang belum terjerat menggunakan NAPZA, terutama dari usia remaja/pelajar.

Beberapa faktor yang melatarbelakangi remaja melakukan penyalahgunaan NAPZA antara lain kurangnya pengetahuan terhadap NAPZA sehingga mengakibatkan sikap atau perilaku penggunaan zat terlarang tersebut. Hasil penelitian terdahulu yang dilakukan oleh Yeliasti (2014) mengenai Hubungan Pengetahuan dan Sikap terhadap Perilaku Penyalahgunaan Narkoba pada siswa/i SMP menjelaskan bahwa 38,5\% responden kurang memiliki pengetahuan mengenai narkoba. Hasil penelitian juga menjelaskan bahwa sebagian besar siswa memiliki sikap positif untuk menjauhi narkoba, namun demikian terdapat $1,9 \%$ yang mempunyai sikap kurang positif menjauhi narkoba.
SMK Sepuluh November Semarang merupakan salah satu Sekolah Menengah Kejuruan ternama di Kota Semarang. Akreditasi sekolah yang dikeluarkan oleh Badan Akreditasi Sekolah (BAS) untuk SMK tersebut adalah A. SMK tersebut juga memiliki banyak siswa dan dengan tingkat mobilitas yang tinggi di Kota Semarang maka tidak menutup kemungkinan terdaat pelajar yang menyalahgunakan NAPZA.

Berdasarkan landasan berbagai permasalahan tersebut diatas, guna mencegah terjadinya penyalahgunaan NAPZA dikalangan pelajar maka perlu mengetahui bagaimana sikap pelajar tentang penyalahgunaan NAPZA serta pengetahuan yang dimiliki pelajar mengenai NAPZA. Dengan demikian penelitian ini akan mengkaji lebih dalam mengenai "Pengetahuan dan sikap remaja terhadap penggunaan napza disekolah menengah atas dikota semarang".

\section{METODE}

Jenis Penelitian ini merupakan penelitian kuantitatif dengan metode survei analitik. menggunakan rancangan survei cross sectional. Sampel penelitan sebanyak 150 remaja yang memenuhi kriteria menggunakan kuesioner kemudian diuji menggunakan uji chi square pada tingkat kepercayaan $95 \%$ dari program SPSS versi 19. Analisa data menggunakan uji chi square.

\section{HASIL}

Hasil penelitian dapat dilihat pada tabel berikut.

Tabel 1

Distribusi frekuensi responden berdasarkan jenis kelamin, pengetahuan dan sikap remaja tentang penggunaan napza $(\mathrm{n}=150)$

\begin{tabular}{ccc}
\hline Jenis Kelamin & $\mathrm{f}$ & $\%$ \\
\hline Laki-laki & 107 & 71.3 \\
Perempuan & 43 & 28.7 \\
\hline Total & 150 & 100 \\
\hline
\end{tabular}

Tabel 2

Distribusi frekuensi responden berdasarkan usia , pengetahuan dan sikap remaja tentang penggunaan napza $(n=150)$

\begin{tabular}{ccc}
\hline Usia (Tahun) & $\mathrm{f}$ & $\%$ \\
\hline 15 & 17 & 11.3 \\
16 & 81 & 54.0 \\
17 & 43 & 28.7 \\
18 & 9 & 6.0 \\
\hline Total & 150 & 100 \\
\hline
\end{tabular}




\section{Tabel 3}

Distribusi frekuensi responden berdasarkan tempat tinggal, pengetahuan dan sikap remaja tentang penggunaan napza $(n=150)$

\begin{tabular}{ccc}
\hline Tinggal bersama & $\mathrm{f}$ & $\%$ \\
\hline Kedua orang tua & 130 & 86.7 \\
Salah satu orang tua & 11 & 7.3 \\
Wali & 6 & 6.0 \\
\hline Total & 150 & 100 \\
\hline
\end{tabular}

Tabel 4.

Distribusi frekuensi responden berdasarkan penggunaan NAPZA, pengetahuan dan sikap remaja tentang penggunaan napza $(\mathrm{n}=150)$

\begin{tabular}{ccc}
\hline Menggunakan NAPZA & $\mathrm{f}$ & $\%$ \\
\hline Menggunakan & 34 & 22.7 \\
Tidak menggunakan & 116 & 77.3 \\
\hline Total & 150 & 100 \\
\hline
\end{tabular}

Tabel 5

Distribusi frekuensi responden berdasarkan pengetahuan NAPZA Pengetahuan dan sikap remaja tentang penggunaan napza $(\mathrm{n}=150)$

\begin{tabular}{ccc}
\hline Pengetahuan NAPZA & $\mathrm{f}$ & $\%$ \\
\hline Kurang baik & 73 & 48.7 \\
Baik & 77 & 51.3 \\
\hline Total & 150 & 100 \\
\hline
\end{tabular}

Tabel 6

Distribusi frekensi responden berdasarkan sikap terhadap NAPZA, Pengetahuan dan sikap remaja tentang penggunaan napza $(n=150)$

\begin{tabular}{ccc}
\hline Sikap & $\mathrm{f}$ & $\%$ \\
\hline Kurang baik & 48 & 32.0 \\
Baik & 102 & 68.0 \\
\hline Total & 150 & 100 \\
\hline
\end{tabular}

Tabel 7

Pengetahuan remaja tentang penggunaan napza $(n=150)$ Pengetahuan

Pengguna napza

\begin{tabular}{lllll} 
pengguna & $\begin{array}{l}\text { Tdk } \\
\text { pengguna }\end{array}$ & Total & $p$ & $\mathrm{r}$ \\
\hline
\end{tabular}

\begin{tabular}{|c|c|c|c|c|c|c|c|c|}
\hline & & & & & & & & \\
\hline & $f$ & $\%$ & $\mathrm{f}$ & $\%$ & $\mathrm{f}$ & $\%$ & & \multirow{4}{*}{0.343} \\
\hline Baik & 6 & 7.8 & 71 & 92.2 & 77 & 100 & \multirow[b]{2}{*}{0.000} & \\
\hline Kurang baik & 28 & 38.4 & 45 & 61.6 & 73 & 100 & & \\
\hline Total & 34 & 22.7 & 116 & 77.3 & 150 & 100 & & \\
\hline
\end{tabular}

Tabel 8

Sikap remaja tentang penggunaan napza $(n=150)$

\begin{tabular}{|c|c|c|c|c|c|c|c|c|}
\hline \multirow[t]{3}{*}{ Sikap } & \multicolumn{4}{|c|}{ Penggua Napza } & \multirow{2}{*}{\multicolumn{2}{|c|}{ Total }} & \multirow{3}{*}{$p$} & \multirow{3}{*}{$\mathrm{r}$} \\
\hline & \multicolumn{2}{|c|}{ Pengguna } & \multicolumn{2}{|c|}{ Tdk pengguna } & & & & \\
\hline & $\mathrm{f}$ & $\%$ & $\mathrm{f}$ & $\%$ & $\mathrm{f}$ & $\%$ & & \\
\hline Baik & 16 & 15.7 & 86 & 92.2 & 102 & 100 & & \\
\hline Kurang baik & 18 & 37.5 & 30 & 61.6 & 48 & 100 & 0.000 & 0.236 \\
\hline Total & 34 & 22.7 & 116 & 77.3 & 150 & 100 & & \\
\hline
\end{tabular}


Tabel 9

Pengetahuan dan sikap remaja tentang penggunaan napza $(\mathrm{n}=150)$

\begin{tabular}{|c|c|c|c|c|c|c|c|c|}
\hline \multirow[t]{3}{*}{ pengetahuan } & \multicolumn{4}{|c|}{ Sikap } & \multirow{2}{*}{\multicolumn{2}{|c|}{ Total }} & \multirow{3}{*}{$p$} & \multirow{3}{*}{$r$} \\
\hline & \multicolumn{2}{|c|}{ Baik } & \multicolumn{2}{|c|}{ Kurang baik } & & & & \\
\hline & $\mathrm{f}$ & $\%$ & $\mathrm{f}$ & $\%$ & $\mathrm{f}$ & $\%$ & & \\
\hline Baik & 21 & 27.3 & 56 & 72.7 & 77 & 100 & \multirow{3}{*}{0.202} & \multirow{3}{*}{0.343} \\
\hline Kurang baik & 27 & 37.0 & 46 & 63.0 & 73 & 100 & & \\
\hline Total & 48 & 32.0 & 102 & 68.0 & 150 & 100 & & \\
\hline
\end{tabular}

\section{PEMBAHASAN}

Tabel 1 menjelaskan bahwa responden di dominasi oleh jenis kelamin laki-laki yaitu sebesar $71.3 \%$ atau sejumlah 107 responden dan sisanya sebanyak 43 responden atau sebesar $28.7 \%$ adalah perempuan. Pada penelitian ini peluan untuk menjadi responden antara laki-laki dan perempuan adalah sama, sehinga tidak ada ketentuan untuk penyamaan jumlah antara responden laki-laki dan perempuan. Hal tersebut karena peneliti tidak memasukkan jenis kelamin ke dalam kriteria penelitian. Perbedaan jumlah responden berdasarkan jenis kelamin terjadi dalam penelitian ini dimungkinkan karena siswa SMK sebagian besar berjenis kelamin laki-laki dan kecenderungan penggunaa NAPZA adalah laki-laki.

Tabel 2 menjelaskan bahwa sebagian besar responden berusia 16 tahun yaitu sebanyak 81 responden atau sebesar 54\%. Sedankan frekuensi paling kecil yaitu responden berusia 18 tahun yakni sebanyak 9 responden atau sebesar $6 \%$.

Tabel 3 menjelaskan bahwa sebagian besar responden tinggal bersama kedua orang tua mereka yakni sebanyak 130 responden atau sejumlah $86.7 \%$, dan frekuensi paling sedikit sebanyak 6 responden atau sebesar $6 \%$ tinggal denga wali. Tabel 4 menjelaskan bahwa responden yang tidak menggunakan NAPZA lebih banyak dari pada responden yang menggunakan NAPZA yaitu sebanyak $77.3 \%$. Tabel 5 menjelaskan bahwa pengetahuan responden secara umum adalah baik dengan jawaban benar $>75 \%$ dari total semua soal sebanyak 25 soal. Namun demikan, responden dengan tingkat pengetahuan rendah juga berbanding tipis dengan responden yang memiliki pengetahuan baik yakni sebesar 48.7\% atau sejumlah 73 responden.

Berdasarkan 6 dapat dijelaskan bahwa sikap responden tentang penyalahgunaan NAPZA didominasi dengan kategori sikap baik (68\%) dan sisanya sebesar 32\% responden memiliki sikap kurang baik terhadap penyalahgunaan NAPZA.

Berdasarkan tabel 7 diperoleh sebagian besar responden yang mengunakan NAPZA sebanyak $34(22,7 \%)$ remaja dengan pengetahuan kurang baik sebanyak $73(48,7 \%)$, sedangkan responden yang tidak menggunakan NAPZA sebanyak 116 (77,3\%) dengan pengetahuan yang baik sebanyak 77 (51,3\%). Berdasarkan hasil uji Chi Square $\left(\mathrm{X}^{2}\right)$ pada $\alpha 5 \%$ dengan derajat kepercayaan $95 \%$ menunjukkan bahwa ada hubungan positif antara pengetahuan dengan pengunaan NAPZA yang dibuktikan dengan nilai $p=0.000$ yang kurang dari 0.05. Niai $r$ yang diperoleh dari uji korelasi $=0.343$ sehingga dapat disimpulkan bahwa pengetahuan berhubungan dengan penggunaan NAPZA dengan korelasi cukup. Hasil tersebut menunjukkan bahwa semakin tinggi pengetahuan maka semakin sedikit siswa yang menggunakan NAPZA.

Berdasarkan tabel 7 diperoleh sebagian besar responden yang mengunakan NAPZA sebanyak $34(22,7 \%)$ orang dengan sikap kurang baik sebanyak 48 $(32,0 \%)$, sedangkan responden yang tidak menggunakan NAPZA sebanyak 116 (77,3\%) dengan sikap yang baik sebanyak $102(68 \%)$.

Berdasarkan hasil uji Chi Square (X2) pada $\alpha \quad 5 \%$ dengan derajat kepercayaan 
95\% (lampran uji chi square) menunjukkan bahwa ada hubungan positif antara sikap dengan penggunaan NAPZA yang dibuktikandengan nilai $p=0.003$ yang kurang dari 0.05 . Nilai $r$ hitung sebesar 0.236 mengindikasikan bahwa tingkat korelasi antara sikap dengan penggunaan NAPZA tergolong dalam korelasi lemah. Namun demikian, secara keseluruhan, hasil uji ci square tersebut menunjukkan bahwa ada hubungan yang signifikan antara sikap dengan penggunaan NAPZA yang artinya semakin baik sikap responden terhadap penyalahgunaan NAPZA maka semakin baik pula perilaku siswa terhadap penggunaan NAPZA.

Berdasarkan tabel 9 diperoleh hasil analisis chi Square diperoleh nilai Chi Square signifikasi $p=0,202$. Berdasarkan ketentuan analisis Chi Square dimana nilai probabilitas (p) kurang dari 0,05 artinya tidak terdapat hubungan yang signifikan antara tingkat pengetahuan dengan sikap pada remaja sekolah menengah atas dikota semarang. Yang artinya seseorang yang memiliki pengetahuan baik belum tentu akan bersikap baik walaupun pengetahuan dan sikap dianggap dua hal yang berhubungan. Sedangkan walaupun seseorang berpengetahuan yang baik mengenai NAPZA, namun jika ada kecenderungan orang tersebut memiliki keinginan untuk mencoba, dan terpengaruh lingkungan maka ia akan mencobanya.

\section{SIMPULAN DAN SARAN \\ Simpulan}

Secara umum, hasil penelitian menunjukkan bahwa hampir sebagian besar siswa-siswi SMA Muhammadiyah I dan SMK Sepuluh November Semarang memiliki pengetahua yang baik mengenai NAPZA, golongangolongannya, cara penggunaan dan bahaya yang ditimbulkan dari penyalahgunaan zat-zat tersebut. Umumnya remaja memperoleh informasi mengenai NAPZA dari berbagai sumber di lingkungan sekitar mereka yaitu orangtua, guru, teman dan media. Pengetahuan tentang NAPZA dan penyalahgunaannya akan mengarahkan remaja untuk tidak pernah menggunakan bahkan mencoba zat berbahaya tersebut serta bersikap menolak ajakan teman maupun pengaruh lingkungan untuk menggunakannya. Dengan demikian menjadi sangat penting bagi semua pihak baik sekolah maupun orang tua untuk terus memberikan pengarahan yang baik mengenai bahayanya penyalahgunaan NAPZA bagi masa depan remaja.

\section{Saran}

Berdasarkan hasil penelitian dan pembahasan mengenai pengetahuan dan sikap remaja terhadap penggunaan NAPZA di SMK Sepuluh November Semarang, maka beberapa saran yang dapat peneliti sampaikan antara lain:

1. Bagi Ilmu Keperawatan

Hasil penelitian tersebut diharapkan dapat menambah wawasan perawat mengenai pentingnya pengetahuan mengenai NAPZA sehingga dapat disosialisasikan kepada masyarakat sekitar sehingga dapat mencegah adanya penyalahgunaan NAPZA.

\section{Bagi Masyarakat}

Mengingat begitu besarnya bahaya yang dapat ditimbulkan akibat penyalahgunaan NAPZA baik secara fisik dan psikis, dengan demikian upaya pencegahan harus dilakukan sejak awal dengan meningkatkan pengetahuan remaja mengenai bahaya NAPZA melalui pendidikan di sekolah, keluarga maupun lingkungan masyarakat sehingga dapat meminimalisir penyalahgunaan penggunaan NAPZA.

\section{Bagi Peneliti}

Hasil penelitian ini menyebutkan bahwa terdapat hubungan yang signifikan antara pengetahuan dan sikap dengan penggunan NAPZA, dengan demikian hasiltersebut dapat digunakan sebagai rujukan bagi penelitian selanjutnya mengenai penyalahgunaan NAPZA dengan menggunakan variabel prediktor lain selain pengetahuan dan sikap remaja.

\section{DAFTAR PUSTAKA}

Arikunto, Suharsini. (2010). Prosedur Penelitian Suatu Pendekatan Praktis (edisirevisi, 2010). Jakarta: PT Rineka Cipta. 2010.

Arikunto, (2006). Suharsimi. Prosedur Penelitian: Suatu Pendekatan Praktik. Edisi Revisi. Jakarta: Rineka Cipta.

Amran, Yuli. (2012). Pengolahan dan Analisis Data Statistic di Bidang Kesehatan. Jakarta: Rineka Cipta 
Mukti Ali. (2008). Metode Memahami Agama Islam. Jakarta: Bulan Bintang

Hidayat A.A.A. (2009) Metode Penelitian Keperawatan Dan Teknik Analisa Data. Jakarta. Salemba Medika.

King, Laura K. (2012). PsikologiUmum. Jakarta: Salemba Humanika.

Mardani. (2008). Penyalahgunaan Narkoba. Jakarta: PT. Raja Grafindo Persada,

Maeyer, J.D., Wouter, V., Eric, B. (2009). Exploratory Study on Drug Users' Perspectives on Quality of Life: More than Health-Related Quality of Life? soc Indic Res (2009) 90:107-126 retrivied DOI 10.1007/s1125-008-93157

Martono, Lidya Harlina dan Joewana, Satya. (2008). Membantu Pemulihan Pecandu Narkoba dan Keluarganya. Jakarta: Balai Pustaka

Nevid, J.S,. Ratus, S.A, Greene, B. (2005). Psikologi Abnormal;

Notoatmodjo, Soekidjo., (2010). Ilmu Perilaku Kesehatan. Jakarta : Rineka Cipta

Notoatmodjo, Soekidjo. (2012). Promosi Kesehatandan Perilaku Kesehatan. Jakarta: Rinekacipta.

Notoatmodjo. (2010). Metodologi Penelitian Kesehatan. Jakarta: Rineka Cipta.

Notoatmodjo, Soekidjo. (2007). Promosi Kesehatandan Perilaku Kesehatan. Jakarta: Rinekacipta.

Nursalam. (2011). Konsep dan Metodologi Keperawatan (ed. 2). Jakarta: Salemba Medika.

Nursalam. (2008). Konsepdan Penerapan Metodologi Penelitian Ilmu Keperawatan. Jakarta: Salemba Medika. 